\title{
SŁUŻBA RODZINIE W RAMACH CHRZEŚCIJAŃSKIEJ KONCEPCJI PAŃSTWA
}

Wspólnota rodzinna funkcjonuje pomiędzy osobą a społeczeństwem. Takie stwierdzenie jest możliwe przy założeniu istnienia hierarchicznie uporządkowanej rzeczywistości społecznej. Nawiązując do powyższej zależności, za Leonem Dyczewskim można przyjąć następujące określenie rodziny: „Rodzina jest wspólnotą osób i instytucją społeczną opartą na miłości i wolnym wyborze kobiety i mężczyzny połączonych małżeństwem, którzy odpowiadając wzajemnie za siebie, rodzą i wychowują następne pokolenie $\mathrm{w}$ taki sposób, aby ono także rodziło i wychowywało nowe pokolenia"1 ${ }^{11}$ Rodzina przygotowuje osoby do partycypowania w życiu społecznym, a spełniając funkcję prokreacyjną, zapewnia trwanie społeczeństwu. Celem niniejszej publikacji, powstałej na podstawie nauczania społecznego Kościoła, jest ukazanie charakteru zobowiązań państwa wobec rodziny $\mathrm{w}$ ramach prowadzonej polityki

* Janusz Szulist - prezbiter diecezji pelplińskiej. Doktor habilitowany nauk teologicznych z zakresu katolickiej nauki społecznej. Adiunkt w Zakładzie Teologii Moralnej i Katolickiej Nauki Społecznej na Wydziale Teologicznym Uniwersytetu Mikołaja Kopernika w Toruniu. Wykładowca katolickiej nauki społecznej w Wyższym Seminarium Duchownym w Pelplinie.

${ }^{1}$ L. Dyczewski, Rodzina. Społeczeństwo. Państwo, Lublin 1994, s. 27. 
społecznej. Jest to forma relacji zwrotnej $\mathrm{w}$ stosunku do dobra, jakie rodzina wnosi do życia społeczności państwowej. Z tego względu należy jasno zdefiniować przesłanki sprzyjające pomocy rodzinie ze strony społeczności, gdyż dla państwa jest to kwestia egzystencjalna.

Niniejsza publikacja składa się z trzech części. W pierwszej z nich jest przedstawiona charakterystyka rodziny poprzez ukazanie jej konstytutywnych elementów. W drugiej części, przy założeniu wspólnotowego i instytucjonalnego charakteru życia wspólnoty rodzinnej, zostanie zaprezentowana relacja rodziny do społeczeństwa. Trzecia, ostatnia część dotyczy postulatów polityki społecznej, realizowanej przez społeczność państwową.

\section{KONSTYTUTYWNE ELEMENTY ŻYCIA RODZINNEGO}

Miłość stanowi zasadniczą wartość i fundament życia społecznego. Podmiotami zaangażowanymi $\mathrm{w}$ realizację postulatów miłości są nie tylko osoby, ale również rodziny. $\mathrm{W}$ ognisku rodzinnym człowiek uczy się po raz pierwszy miłości chrześcijańskiej, którą następnie kieruje się $\mathrm{w}$ realiach społecznych. Wyznacznikami nacechowanego miłością postępowania osób oraz rodzin są takie wartości, jak wierność, prokreacja oraz sakramentalność. Życie społeczne ukonstytuowane w rodzinie chrześcijańskiej podkreśla naturalne ukierunkowanie człowieka na Boga. Element nieskończoności dopełnia rzeczywistość ziemską, w ramach której osoba jako swoista istota rodzinna urzeczywistnia Królestwo Boże, będące wyrazem miłości Chrystusowej.

\subsection{MIŁOŚĆ ISTOTĄ ŻYCIA RODZINNEGO}

Nauczanie Soboru Watykańskiego II oraz wypowiedzi Jana Pawła II i Benedykta XVI o życiu rodzinnym zawierają następujące elementy wspólne: miłość, przymierze, wspólnota oraz rozwój². Miłość małżeńska i w konsekwencji także miłość rodzinna dotyczą relacji między osobami. W ramach miłości dochodzi do odkrycia drugiego człowieka jako osoby. Miłość w nauce Kościoła jest zatem wyznacznikiem personali-

${ }^{2}$ Zob. tenże, Rodzina, w: Katolicka nauka społeczna. Podstawowe zagadnienia z życia spotecznego i politycznego, red. S. Fel, J. Kupny, Katowice 2007, s. 89n. 
zmu, a także w najwyższym stopniu służy kształtowaniu społeczności, troszczącej się przede wszystkim o dobro osoby. Analizując fenomen miłości małżeńskiej, należy ponadto wskazać na jej dwie własności. Po pierwsze: miłość małżeńska i rodzinna jest miłością ofiarną. Istotę trwania małżeństwa i rodziny stanowi bezinteresowny dar z siebie dla ukochanej osoby. Kształtowana w ten sposób ofiarność przekłada się bezpośrednio na jedność małżeńską i rodzinną, która umocniona łaską sakramentalną - będącą wyrazem miłości Boga do człowieka - trwa aż do śmierci. Po drugie: miłość małżeńska i rodzinna cechuje się integralnością. Obejmuje więc całego człowieka w jego wymiarze duchowym i cielesnym³ ${ }^{3}$.

Konkretne formy miłości małżeńskiej, wyrażające się w przymierzu małżeńskim, oraz tradycje przekazywane w tym zakresie, stanowią w znacznej mierze wypadkową czasoprzestrzennych uwarunkowań życia konkretnych rodzin ${ }^{4}$. Przymierze między małżonkami, realizowane w ramach rzeczywistości ziemskiej, jest - jak naucza Jan Paweł II - „obrazem i znakiem Przymierza łączącego Boga z Jego ludem”5. Miłość, jaką Bóg darzy człowieka, znajduje odzwierciedlenie w miłości między małżonkami i pozostałymi członkami rodziny. W nauce Kościoła jest mowa o miłości zapewniającej wyłączność relacji pomiędzy Bogiem a człowiekiem oraz w obrębie małżeństwa i rodziny. Wymiar Przymierza ostatecznie warunkuje wzajemność pomiędzy miłością a wiernością i upoważnia do

${ }^{3}$ Por. Jan Paweł II, Jesteście solq ziemi (Msza św. i zawarcie sakramentu małżeństwa, 12 VI), "L'Osservatore Romano" 8/1994 (wyd. pol.), s. 29n.; Kompendium nauki społecznej Kościota, red. Papieska Rada „Iustitia et Pax”, Kielce 2005, 221n. (cyt. dalej: KNSK); K. Majdański, Wspólnota życia i mitości. Zarys teologii matżeństwa i rodziny, Poznań 1983, s. 84n. Koncepcję integralnego rozwoju przedstawił Paweł VI w encyklice Populorum progressio: „Rozwój, o którym mówimy, nie ogranicza się jedynie do postępu gospodarczego. Aby był prawdziwy, powinien on być zupełny, to znaczy winien przyczyniać się do rozwoju każdego człowieka i całego człowieka". Do powyższej charakterystyki jako przesłania Populorum progressio nawiązał Benedykt XVI w Caritas in veritate. Por. Paweł VI, Encyklika o popieraniu rozwoju narodów (Populorum progressio), w: Dokumenty nauki spotecznej Kościoła, red. M. Radwan, L. Dyczewski, A. Stanowski, Rzym-Lublin 1987, cz. 1, 14 (cyt. dalej: PP); Benedykt XVI, Encyklika "Caritas in veritate". O integralnym rozwoju ludzkim w mitości i prawdzie, Kraków 2009, 11 (cyt. dalej: CiV).

${ }^{4}$ Por. Konstytucja duszpasterska o Kościele w świecie wspótczesnym "Gaudium et spes", w: Sobór Watykański II. Konstytucje. Dekrety. Deklaracje, wyd. 3, Poznań 1967, 48n. (cyt. dalej: KDK).

5 Jan Paweł II, Adhortacja Apostolska „Familiaris consortio", Wrocław 1993, 12 (cyt. dalej: FC); tenże, Matżeństwo w integralnym dziedzictwie Przymierza, „L'Osservatore Romano" 10/1982 (wyd. pol.), s. 4n.; tenże, Czystość - cnota $i$ dar, "L'Osservatore Romano" 3/1981 (wyd. pol.), s. 6. 
mówienia o miłości wiernej zarówno w stosunku do Boga, jak członków rodziny ${ }^{6}$.

Małżeństwo i rodzina są ukierunkowane na autentyczny rozwój, który w interpretacji Pawła VI polega na tym, że zarówno jednostki, jak i ogół ludzi, przechodzą z mniej ludzkich warunków życia do warunków bardziej godnych człowieka"7. Rozwój w ramach rodziny oznacza w pierwszej kolejności proces wychowania, a więc kształtowania osobowości. Dzięki niemu możliwe staje się zarówno doskonalenie własnych naturalnych uzdolnień, jak też mobilizowanie członków rodziny do urzeczywistniania zasad moralności, ukonstytuowanych w miłości chrześcijańskiej. Rozwój realizowany na poziomie rodziny powinien skutkować przemianą charakteru życia społecznego, aby odpowiadało ono potrzebom poszczególnych osób i zapewniało możliwość osiągnięcia wysokiego poziomu dobrobytu. Wartości, którymi żyje rodzina, powinny sprzyjać pogłębianiu humanistycznego wymiaru społeczeństwa ${ }^{8}$.

\subsection{GENEZA ŻYCIA RODZINNEGO}

W aspekcie chronologicznym i logicznym małżeństwo zyskuje pierwszeństwo w stosunku do rodziny. Autorzy Kodeksu Prawa Kanonicznego stwierdzają w tym kontekście: „Małżeńskie przymierze, przez które mężczyzna i kobieta tworzą ze sobą wspólnotę całego życia, skierowaną ze swej natury do dobra małżonków oraz do zrodzenia i wychowania potomstwa, zostało między ochrzczonymi podniesione przez Chrystusa Pana do godności sakramentu" (kan. 1055, § 1). Element trwałości zawiązanej sakramentalnie rodziny znajduje wyraz w Konstytucji duszpasterskiej o Kościele w świecie wspótczesnym: "Głęboka wspólnota życia i miłości małżeńskiej ustanowiona przez Stwórcę i unormowana Jego prawami, zawiązuje się przez przymierze małżeńskie, czyli przez nieodwołalną osobistą zgodę. W ten sposób aktem osobowym, przez który małżonkowie wzajemnie się sobie oddają i przyjmują, powstaje z woli Bożej instytucja trwała także wobec społeczeństwa"”.

${ }^{6}$ Por. FC 12; tenże, Matżeństwo w integralnym dziedzictwie Przymierza, s. 4n.

7 PP 20.

${ }^{8}$ Zob. tamże; Jan Paweł II, Czystość - cnota i dar, s. 6; L. Dyczewski, Rodzina polska i kierunki jej przemian, Warszawa 1981, s. 38-42.

${ }^{9}$ KDK 48; por. również: Jan Paweł II, Jesteście świadkami wewnętrznej prawdy mitości, „L'Osservatore Romano” 6/1981 (wyd. pol.), s. 11. 
Józef Majka, powołując się na poglądy św. Augustyna z Hippony, wskazuje na trzy wartości, mające swoje źródło w ścisłej relacji pomiędzy małżeństwem a rodziną. Człowiek potrzebuje bowiem niezmiennych wartości, aby w ten sposób wytrwale zmierzać do celu, jakim jest świętość. Pierwszą z takich wartości jest wierność („fides”). Małżonkowie i osoby tworzące rodzinę darzą się wzajemnym zaufaniem, korelującym z następującymi stanami ducha: „uzyskać pewność, przeżywać poczucie bezpieczeństwa, obdarzyć życzliwością i oddaniem itd." Wierność zachodzi w perspektywie dobra. Osoby ufające sobie zakładają istnienie dobra w drugim człowieku; są gotowe do otwarcia na owo dobro, którym jest druga osoba. Świadomość dobra wzbudza poczucie pewności i spełnienia. Otwarcie podmiotu na innych ludzi jest zatem warunkiem inkorporacji w dobru. Przyjmując hierarchiczną strukturę świata należy stwierdzić, że człowiek posiada zdolność uczestnictwa w coraz pełniejszym dobru, znajdującym absolutne spełnienie w Dobru Najwyższym, czyli Bogu. Odniesienie do Boga $\mathrm{w}$ ramach wymiany lub uczestnictwa w dobru, jakim jest osoba, nadaje wierności charakter nadprzyrodzony. Ów element transcendencji umacnia więź międzyludzką, a ściślej więź pomiędzy osobami, które nawzajem sobie zawierzyły. Relacje nacechowane zaufaniem stanowią fundament miłości małżeńskiej i rodzinnej. Rodzice i małżonkowie, krzewiący postawę zaufania, wzrastają jednocześnie w miłości. Otwarcie na dobro drugiej osoby - wraz z rozwojem osobowości - oddziałuje $\mathrm{w}$ konsekwencji na różne inne dziedziny życia. Postawa zaufania zaczyna wówczas przenikać również relacje między rodzinami, a także odniesienie rodziny do szeroko rozumianej społeczności, w tym również społeczności państwowej. W interesie państwa powinno znajdować się krzewienie postawy zaufania $\mathrm{w}$ rodzinie, gdyż ten właśnie stan czyni bardziej skutecznym dążenie człowieka do dobra ${ }^{10}$.

Drugą wartością, określającą istotę życia małżeńskiego i rodzinnego, jest prokreacja („proles”). Powołując do istnienia nowe istoty ludzkie, rodzice nie tylko konsumują miłość, którą siebie darzą, ale przede wszystkim służą społeczeństwu ${ }^{11}$. Funkcja prokreacyjna jest wpi-

${ }^{10}$ Por. tenże, Rodzina źródtem mitości. Orędzie na Światowy Dzień Pokoju (1 stycznia 1994), „L'Osservatore Romano" 1/1994 (wyd. pol.), 1n.; tenże, Nieprzemijające wartości encykliki (Przemówienie, 26 XI 1993r.), "L'Osservatore Romano" 2/1994 (wyd. pol.), 1-4; J. Majka, Etyka społeczna i polityczna, Warszawa 1993, s. 90nn.; W. Półtawska, Piękna mitość, „L'Osservatore Romano” 11/1994 (wyd. pol.), s. 55.

${ }^{11}$ Realizacja postulatów miłości małżeńskiej zmierza do powoływania nowych 
sana w koncepcję integralności osoby ludzkiej. Poczęty człowiek stanowi nie tylko przejaw ilościowego wzrostu wspólnoty ludzkiej; każda istota ludzka wnosi bowiem bezcenny wkład $\mathrm{w}$ kształtowanie ducha i kultury, czyli immanentnego aspektu życia społecznego (aspektu jakościowego życia rodzinnego). Zadanie społeczeństwa w kwestii zachowania wartości prokreacji $\mathrm{w}$ całym jej wymiarze dotyczy realizacji dwóch celów. Pierwszy z nich posiada charakter negatywny. Jego istotę stanowi wykluczenie tych działań ze strony instytucji reprezentujących społeczeństwo, które zmierzałyby do uprzedmiotowienia jednostki i rodziny, czyli wszelkich przejawów „technicyzacji procesu rodzenia". Drugi cel ma charakter pozytywny. Dotyczy bowiem stworzenia przez społeczeństwo, a ściślej przez różnego rodzaju instytucje, atmosfery umożliwiającej zachowanie podmiotowości w kwestii procesu rodzenia ${ }^{12}$.

Trzecią wartością, kształtującą esencję życia małżeńskiego i rodzinnego, jest sakrament. Sakrament małżeństwa otwiera człowieka na tajemnicę, jaką jest Boże życie. Rzeczywistość sakramentalna odsłania przed osobą możliwość rozwoju ukierunkowanego na nieskończoność, co przekłada się na transcendowanie w kierunku Boga. Na tej drodze człowiek zdobywa wciąż nowe walory bytowe, aż do pełni życia osobowego w Bogu. Zakwestionowanie wartości sakramentalnej małżeństwa i rodziny oznacza natomiast wykluczenie elementu nadprzyrodzoności z relacji społecznych. Jest to stan zupełnego spłaszczenia relacji społecznych, redukowania ich jedynie do działań o charakterze biologicznym i czysto mechanicznym. Naturalizacja rzeczywistości społecznej stanowi cechę kultury materialistycznej i konsumpcyjnej, dominującej współcześnie $\mathrm{w}$ dobie globalizmu ${ }^{13}$.

istot ludzkich do życia: „Małżeństwo i miłość małżeńska z natury swej skierowane są ku płodzeniu i wychowywaniu potomstwa". Służba życiu stanowi wyraz troski o dobro wspólne rodziny. Jan Paweł II w Liście do rodzin nazywa wprost poczęte dziecko dobrem wspólnym rodziny. Por. KDK 50; Jan Paweł II, List do rodzin, w: tenże, List do rodzin. List do dzieci, Częstochowa 2004, s. 36 (cyt. dalej: LdR).

${ }^{12}$ Por. tenże, Dwie wielkie prawdy o rodzinie, "L'Osservatore Romano" 5/1982 (wyd. pol.), s. 16; A. L. Trujillo, Pasterska troska Ojca Świętego o rodzinę, „L'Osservatore Romano" 4/1994 (wyd. pol.), s. 51n.; J. Majka, dz. cyt., s. 92n.; L. Dyczewski, Rodzina polska i kierunki jej przemian, s. 111n.

${ }^{13}$ Por. Jan Paweł II, Matżeństwo jako sakrament. Zarysowanie problemu, „L'Osservatore Romano" 7-8/1982 (wyd. pol.), s. 12n.; tenże, Rodzina źródtem mitości..., 2; tenże, Jesteście solq ziemi..., s. 29n.; KNSK 220; J. Majka, dz. cyt., s. 93nn. 


\section{RODZINA WOBEC SPOŁECZNOŚCl}

Rodzina i społeczeństwo stanowią dwie rzeczywistości, w naturalny sposób od siebie zależne. Leon Dyczewski stwierdza, iż „rodzina i społeczeństwo połączone są żywymi i organicznymi więzami” oraz „wzajemnie się uzupełniają", służąc ostatecznie rozwojowi jednostek i wspólnot. W ramach tej relacji pierwszeństwo zyskuje oczywiście rodzina, ponieważ prawa, jakimi kieruje się społeczność, są formułowane na podstawie uwarunkowań życia rodzinnego. „Rodzinę, opartą na związku małżeńskim zawartym dobrowolnie, jednym i nierozerwalnym - należy uważać za pierwszy i naturalny związek społeczności ludzkiej. Dlatego należy otoczyć ją jak największą troską - tak w sprawach gospodarczych i socjalnych, jak w dziedzinie poglądów i obyczajów - wszystko w tym celu, aby rodzinę umocnić oraz dopomóc w pełnieniu właściwych jej zadań"14.

W perspektywie relacji rodziny względem społeczności uwydatnia się aspekt wspólnotowy i instytucjonalny wspólnoty rodzinnej. Rodzina stanowi wspólnotę osób, co podkreśla Jan Paweł II w adhortacji Familiaris consortio. Wspólnotowy aspekt rodziny wyraża się w relacjach osobowych, pośród których należy wymienić: „oblubieńczość, ojcostwo-macierzyństwo, synostwo oraz braterstwo". Wskazane powyżej relacje możliwe są tylko między osobami i w największym stopniu zapewniają rozwój osobowy. Wspólnotowy charakter rodziny realizowany jest w ramach Kościoła w dwojaki sposób. Po pierwsze, wspólnota Kościoła stanowi wzorzec dla wspólnoty rodzinnej. Po drugie, pomiędzy Kościołem a rodziną zachodzi relacja o charakterze przyczynowym. Sakramenty udzielane za pośrednictwem Kościoła umożliwiają bowiem wzrost w świętości, a ponadto dzięki współpracy z łaską sakramentalną człowiek zyskuje przebaczenie grzechów ${ }^{15}$. W aspekcie wspólnotowości można zatem jednoznacznie wyróżnić naturalne otwarcie rodziny oraz - w dalszej kolejności - całej społeczności na Boga. Oznacza to, iż pozbawione perspektywy Transcendencji rodzina i społeczeństwo stają się niezrozumiałe.

${ }^{14}$ Jan XXIII, Encyklika "O pokoju między wszystkimi narodami opartym na prawdzie, sprawiedliwości, miłości i pokoju" (Pacem in terris), w: Dokumenty nauki społecznej Kościoła, red. M. Radwan, L. Dyczewski, A. Stanowski, Rzym-Lublin 1987, cz. 1, 16 (cyt. dalej: PT); por. również: Jan Paweł II, List Papieża na XVIII Międzynarodowy Kongres Rodziny, „L'Osservatore Romano” 5/1995 (wyd. pol.), s. 64; L. Dyczewski, Rodzina, s. 99.

15 Por. FC 15; LdR 7; K. Majdański, dz. cyt., s. 82. 
W wymiarze instytucjonalnym rodzina ukształtowana jest na wspólnocie zawiązanej w sakramencie małżeństwa. Instytucjonalny aspekt rodziny stanowi również przedmiot analiz socjologów, takich jak Franciszek Adamski, który stwierdza: „Gdy mówimy o rodzinie jako instytucji społecznej, zawsze mamy na myśli jej formalne ustanowienie i funkcjonowanie według określonych norm społecznych $\mathrm{w}$ ramach danego systemu społecznej kontroli"16. Rodzina jako instytucja jest wpisana w struktury społeczne i w istotowy sposób przyczynia się do kształtowania dobra wspólnego społeczeństwa ${ }^{17}$.

Rodzina jako instytucja realizuje się w strukturach społecznych poprzez spełnianie właściwych sobie funkcji ${ }^{18}$. Funkcje wspólnoty rodzinnej warunkują trwanie społeczeństwa. $Z$ tego względu realizacja owych funkcji powinna być przedmiotem troski osób realizujących odpowiedzialne zadania społeczne. Współcześnie jednak funkcje instytucjonalne rodziny coraz częściej są przejmowane przez podmioty życia społecznego inne niż wspólnota rodzinna ${ }^{19}$.

\section{PAŃSTWO NA RZECZ RODZINY}

Wspólnotowy oraz instytucjonalny charakter rodziny podlega realizacji w ramach społeczności państwowej. Spełnianie powyższego zadania jest możliwe, gdyż państwo stanowi „wspólnotę wspólnot”, a ponadto społeczność państwowa wyraża swoje istotowe funkcje w ramach działań instytucjonalnych. Odniesienie do instytucji i wspólnoty ukazuje specyfikę państwa w koncepcji chrześcijańskiej, w której centralne miejsce zajmuje nie tylko osoba, ale również rodzina. Troska państwa o rodzinę przyjmuje formę polityki prorodzinnej.

${ }^{16}$ F. Adamski, Rodzina. Wymiar społeczno-kulturowy, Kraków 2002, s. 30.

17 Por. Jan Paweł II, Dwie wielkie prawdy o rodzinie, s. 15; L. Dyczewski, Rodzina. Społeczeństwo. Państwo, s. 14n.; A. Zwoliński, Życie społeczno-polityczne, w: T. Borutka, J. Mazur, A. Zwoliński, Katolicka nauka społeczna, Częstochowa 1999, s. 197n.

${ }^{18}$ Por. L. Dyczewski, Rodzina, s. 90. Andrzej Zwoliński, charakteryzując zagadnienie rodziny w nauce społecznej Kościoła, dzieli funkcje rodziny na instytucjonalne i osobowe. Pośród funkcji instytucjonalnych badacz wymienia następujące funkcje: prokreacyjna, ekonomiczna, opiekuńcza, socjalizacyjna, stratyfikacyjna oraz integracyjna. Natomiast do funkcji osobowych Zwoliński zalicza funkcję małżeńską, rodzicielską i braterską. Zob. A. Zwoliński, Społeczny wymiar życia rodzinnego, w: T. Borutka, J. Mazur, A. Zwoliński, Katolicka nauka społeczna, Częstochowa 1999, s. 187.

${ }^{19}$ Por. F. Adamski, dz. cyt., s. 29nn. 


\subsection{CHRZEŚCIJAŃSKA KONCEPCJA PAŃSTWA}

Państwo jako instytucja organizująca życie obywateli - oczywiście przy zachowaniu ich podmiotowości - jest zdolne stworzyć optymalne warunki dla bytowania rodzin za sprawą ustaw, organizowania działalności instytucji publicznych oraz kontroli. Realizacja wskazanych powyżej zadań wynika z przyjęcia następującego znaczenia państwa, autorstwa Miłowita Kunińskiego: „Pojęcie państwa odnosi się do władzy politycznej sprawowanej przez rząd i system instytucji politycznych, które służą organizowaniu działań zbiorowych za pomocą podporządkowanego im aparatu administracyjnego" 20 . Fundamentalne znaczenie tak rozumianego państwa dla osoby i rodziny wynika z faktu, iż państwo stanowi wspólnotę naturalną, wyrażającą się $\mathrm{w}$ trzech prawidłowościach dotyczących sposobu egzystowania obywateli: 1. „człowiek przynależy do danej społeczności państwowej przez fakt urodzenia i ma ograniczone możliwości zmiany przynależności państwowej"; 2. państwo stanowi istotowy czynnik w naturalnym procesie doskonalenia się człowieka; 3. udział w życiu państwowym jest uwarunkowany postulatami rozumu naturalnego ${ }^{21}$.

Chrześcijańska koncepcja państwa jako uszczegółowienie powyższych stwierdzeń jest ugruntowana na fragmentach Listu do Rzymian św. Pawła, traktujących o pochodzeniu władzy (por. Rz 13,1), która posiada istotowo służebny charakter. Niezwykle ważne dla ustaleń w kwestii chrześcijańskiej państwowości okazało się również stwierdzenie św. Augustyna z Hippony, iż państwo powinno przede wszystkim troszczyć się o dobro narodu. Filozofowie i teolodzy kolejnych wieków rozwijali myśl o podmiotowości wspólnoty narodowej, której przynależy władza. W czasach współczesnych spójną chrześcijańską koncepcję państwowości sformułował Jacques Maritain. Z perspektywy personalizmu państwo jest „wspólnotą wspólnot”, którą cechuje pluralizm. Wszystkie elementy państwa, a właściwie wspólnoty, zjednoczone są wokół urzeczywistniania dobra wspólnego $w$ ramach struktur społeczności państwowej ${ }^{22}$. Funkcjonowanie hierarchicznie uporządkowanego organizmu społecznego odbywa się według zasady pomocniczości, sformułowanej przez Piusa XI w Quadragesimo anno: ,jak jednostkom ludzkim nie wolno

\footnotetext{
${ }^{20}$ M. Kuniński, Państwo, w: Stownik społeczny, red. B. Szlachta, Kraków 2004, s. 801.

${ }^{21}$ Por. KNSK 221n.; C. Strzeszewski, Katolicka nauka społeczna, Warszawa 1985, s. 493nn.

${ }^{22}$ Por. J. Krucina, Dobro wspólne. Teoria i jej zastosowanie, Wrocław 1972, s. 45nn.
} 
odejmować i przekazywać społeczności tego, co jednostki te z własnej inicjatywy i własną mogą wytworzyć pracą, tak samo jest naruszeniem sprawiedliwości, gdy się to, co mniejsze i niższe społeczności wykonać i dokonać mogą, przydzielić większym i wyższym władzom społecznym; poza tym wyrządza to szkodę wielką i podrywa porządek społeczny. Wszelka czynność społeczna bowiem powinna w pojęciu i istocie swojej wspomagać członki ciała społecznego, nigdy zaś ich nie rozbijać, ani nie wchłaniać"23. Spośród mniejszych społeczności, zajmujących dalsze pozycje w państwowej hierarchii, o których wspomina Pius XI, należy wyróżnić również rodzinę, której podmiotowości oraz rozwojowi powinno sprzyjać państwo. Państwo ma wręcz obowiązek służby rodzinie, która to służba wyznacza istotę jego etosu ${ }^{24}$.

Czesław Strzeszewski podkreśla, iż w nauce chrześcijańskiej istota państwa posiada trojaki charakter, a mianowicie: społeczny, prawny i moralny. Po pierwsze, państwo stanowi społeczność zorganizowana, posiadającą suwerenną władzę oraz zamieszkującą określone terytorium. Władza jest instancją nadrzędną wobec mniejszych grup tworzących państwo, a więc samorządów, rodzin oraz organizacji pracowniczych. Zasadnicza linia podporządkowania wyznaczona jest poprzez odniesienie do dobra wspólnego, któremu wszyscy tworzący państwo - zarówno rządzący, jak i rządzeni - zobowiązani są służyć. Państwo jako społeczność posiada następujące cechy: naturalność (societas naturalis), pełność i skończoność (completa) oraz doskonałość (perfecta). Powyższe własności określają społeczny charakter państwa. Po drugie, państwo ma także wymiar prawny; stoi bowiem na straży przestrzegania prawa przez obywateli. Władza wydaje również akty prawne, które porządkują życie w ramach społeczności. W aspekcie uchwalania aktów prawnych państwo zachowuje wyższość w stosunku np. do rodziny lub grup zawodowych ${ }^{25}$. Po trzecie,

${ }^{23}$ Pius XI, Encyklika "O odnowieniu ustroju społecznego $i$ dostosowaniu go do normy prawa Ewangelii" (Quadragesimo anno), w: Dokumenty nauki społecznej Kościoła, red. M. Radwan, L. Dyczewski, A. Stanowski, Rzym-Lublin 1987, cz. 1, 80 (cyt. dalej: QA); por. również: J. Majka, dz. cyt., s. 251n.

${ }^{24}$ Por. W. Łużyński, Struktury pośrednie pomiędzy jednostkq ludzkq a państwem w nauczaniu społecznym Kościoła, Toruń 2008, s. 85-109.

${ }^{25}$ Państwo powinno troszczyć się o taki porządek prawny, który będzie gwarantował nie tylko jedność rodziny, ale przede wszystkim wskazywał na jej nieodzowny i niezastąpiony charakter względem społeczeństwa. Podobne postulaty formułuje Jan Paweł II w adhortacji Familiaris consortio: „Władze publiczne przekonane o tym, że dobro rodziny stanowi wartość niezastąpioną i nieodzowną we wspólnocie obywateli, winny czynić wszystko co możliwe, celem zabezpieczenia wszelkiej pomocy - gospodarczej, 
moralny charakter istoty państwa wyraża się w przyporządkowaniu do dobra wspólnego. Stanowi przejaw uczestnictwa rządzących i obywateli w dążeniu do wspólnego celu, jakim jest wzrost w personalistycznie pojmowanym dobru wspólnym²6.

\subsection{POLITYKA PRORODZINNA}

Troska państwa o rodzinę przyjmuje postać polityki prorodzinnej. Realizuje się ona przede wszystkim poprzez działalność instytucji publicznych. Ich głównym celem jest dbałość o dobro rodziny przy założeniu, iż wspólnota rodzinna stanowi element nieodzowny dla poprawnego funkcjonowania społeczeństwa, a nawet warunek jego istnienia ${ }^{27}$. Sheila B. Kamerman podkreśla, iż polityka prorodzinna państwa jest „rozumiana jako działania rządu na rzecz dzieci i ich rodzin, a zwłaszcza takiej polityki państwa, której celem jest wywarcie wpływu na sytuacje rodzin dzieci lub poszczególnych osób w ich rolach rodzinnych"28. Współcześnie przedmiotem polityki prorodzinnej jest nie tylko rodzina tradycyjna, ale również tzw. alternatywne formy życia rodzinnego. Marta Najder wyróżnia wśród nich takie zjawiska, jak związki kohabitanckie, samotne matki oraz ojcowie. Do alternatywnych form życia rodzinnego należą również małżeństwa bezdzietne $\mathrm{z}$ wyboru, rodziny rozbite na skutek separacji i rozwodów oraz rodziny zrekonstruowane ${ }^{29}$. Istnienie alternatywnych form życia rodzinnego, którym przypisuje się takie samo znaczenie prawne i instytucjonalne, co rodzinie tradycyjnej, koliduje z nauczaniem

społecznej, pedagogicznej, politycznej, kulturalnej - niezbędnej do tego, ażeby rodziny mogły w sposób ludzki sprostać swoim odpowiedzialnym zadaniom". Por. FC 45.

${ }^{26}$ Por. C. Strzeszewski, dz. cyt., s. 493nn.

${ }^{27} \mathrm{~W}$ interesie społeczności leży troska o rodzinę, co w następujący sposób określił Pius XII: „Rodzina nie jest dla społeczeństwa; lecz o wiele bardziej społeczeństwo dla rodziny. Rodzina jest podstawową komórką, konstytutywnym elementem społeczności państwowej [...]. Jej pierwszym obowiązkiem jest więc bezwarunkowe strzeżenie wartości, które rodzinie zapewniają porządek, godność ludzką, zdrowie i szczęście". Pius XII, Przemówienie (18.9.1951), cyt. za: L. Dyczewski, Rodzina, s. 98n.

${ }^{28}$ S. B. Kamerman, Rodzina: problemy teorii i polityki, w: O polityce rodzinnej. Definicje, zasady, praktyka, „Materiały z Zagranicy”, Warszawa 1994, cyt. za: G. Firlit-Fesnak, Rodziny polskie i polityka rodzinna; stan i kierunki przemian, w: Polityka społeczna. Podręcznik akademicki, red. G. Firlit-Fesnak, M. Szylko-Skoczny, Warszawa 2009, s. 188.

${ }^{29}$ Por. M. Najder, Zagrożenia wspótczesnej rodziny, w: Rodzina we wspótczesności, red. A. Ładyżyński, Wrocław 2009, s. 239. 
Kościoła w kwestii rodziny. Autorzy Karty Praw Rodziny postulują, iż „Władze publiczne winny wspierać instytucjonalną wartość małżeństwa; związki pozamałżeńskie nie mogą być stawiane na równi z małżeństwami zawartymi w sposób właściwy"30. Państwa, które prowadzą politykę pomniejszania roli rodziny - oznaczającą wprowadzenie znaku równości między np. kohabitacją a rodziną tradycyjną - uzasadniają swoje postępowanie postulatem równości i wolności. Tymczasem poprzez działania tego typu państwo jawnie podważa założenia wynikające bezpośrednio $\mathrm{z}$ prawa naturalnego. Mając na uwadze dane teologiczne w kwestii rodziny należy stwierdzić, iż takie działanie wspólnot politycznych jest sprzeczne z wolą Boga, wyrażaną w dziele stworzenia ${ }^{31}$.

Konkretne postulaty polityki prorodzinnej w państwie kierującym się wartościami chrześcijańskimi dotyczą serii tzw. zagadnień szczegółowych, realizowanych $\mathrm{w}$ ramach polityki społecznej. Oddziaływanie państwa przebiega $\mathrm{w}$ trzech kierunkach, określanych mianem instytucjonalnego, kulturowego i materialnego. W zakresie oddziaływania politycznego państwa znajduje się kształtowanie takich instytucji, które będą sprzyjały dobru rodziny ${ }^{32}$. Tylko takie działanie wspólnot politycznych stanowi przejaw rodzinnego charakteru struktur państwowych ${ }^{33}$.

Istotny kierunek zaangażowania państwa na rzecz rodziny jest wyznaczany przez kulturę. Aby przeanalizować ten problem, w pierwszej kolejności należy odwołać się do definicji kultury. W szerokim znaczeniu kultura oznacza „całokształt dorobku ludzkości, zarówno materialnego, jak i duchowego, osiągnięty na przestrzeni dziejów”34. Można zatem stwierdzić, iż mianem kultury określany jest ogół działalności człowieka. Natomiast poszczególne kultury transponowane w działaniu człowieka mają charakter kognitywno-woluntarystyczny, przy stałym ukierunkowaniu aksjologiczno-normatywnym ${ }^{35}$. Za Barbarą Szacką należy wyróżnić

${ }^{30}$ Karta Praw Rodziny przedtożona przez Stolice Apostolskg wszystkim ludziom, instytucjom $i$ władzom zainteresowanym misją rodziny w świecie wspótczesnym, Warszawa 1983, art. 1 (cyt. dalej: KPR).

${ }^{31}$ Por. FC 6; KNSK 227; S. Olejnik, Teologia moralna życia społecznego, Włocławek 2000, s. 344 .

${ }^{32}$ Por. FC 45nn.

33 Por. LdR 17.

${ }^{34}$ A. Dudek, Kultura, w: Encyklopedia nauczania społecznego Jana Pawta II, red. A. Zwoliński, Radom 2003, s. 258.

${ }^{35}$ Por. L. Dyczewski, Kultura polska w procesie przemian, Lublin 1995, s. 15nn.; J. Szulist, W kierunku petniejszego człowieczeństwa. Dobro wspólne jako wzorzec dla personalistycznych odniesień w rzeczywistości społeczno-politycznej, Pelplin 2009, s. 138-148. 
następujące treści, istniejące w ramach wspólnot kulturowych: „wzory sposobów odczuwania, reagowania i myślenia, wartości i wyrastające z tych wartości normy, a także sankcje skłaniające do ich przestrzegania"36. Jan Paweł II w swoim nauczaniu zwraca uwagę na element transcendentny $\mathrm{w}$ kulturze, $\mathrm{z}$ którym są powiązane dwie zasadnicze kwestie. Po pierwsze, człowiek jest ukierunkowany w swoim działaniu na wartości, posiadające swoją najwyższą formę w Bogu. Po drugie, wyznawana religia stanowi istotowy element każdej kultury, w znaczącym stopniu określający jej charakter ${ }^{37}$.

Rodzina interpretowana jako wspólnota jest podmiotem kształtującym kulturę $w$ jej wymiarze duchowym (np. realizacja funkcji socjalizacyjno-wychowawczej) oraz w jej wymiarze materialnym (np. dzieła sztuki). Leon Dyczewski, określając zadania państwa wobec rodziny, wskazuje na takie elementy ludzkiej duchowości, jak „ochrona i wzmacnianie tradycji rodzinnych, wartości etycznych, religijnych i społecznych". Zachowanie i realizacja wskazanych powyżej elementów kultury powinna leżeć $\mathrm{w}$ interesie państwa interpretowanego integralnie, a więc posiadającego duchową istotę, w której zasadniczy udział mają osoby oraz rodziny ${ }^{38}$. Konkretne zadania państwa wobec rodziny w zakresie kształtowania kultury dotyczą aspektów wolności religijnej oraz pomocy edukacyjno-wychowawczej. Postulat wolności religijnej, jaką powinna cieszyć się rodzina, został określony w Karcie Praw Rodziny: „Przyszli małżonkowie posiadają prawo do wolności religijnej; tak więc żądanie odrzucenia wiary lub zmiany wyznania niezgodnie z sumieniem, stawiane jako warunek zawarcia małżeństwa, jest pogwałceniem tego prawa" ${ }^{\prime \prime 3}$. Rodzice mają prawo do zachowania przyjętych przekonań religijnych. Państwo jest zobowiązane do zapewnienia rodzicom możliwości nieskrępowanego przekazywania tradycji religijnych swojemu potomstwu ${ }^{40}$. Natomiast polityka edukacyjna, drugi typ działań państwa w stosunku do rodziny na gruncie kultury, powinna mieć na celu przestrzeganie następującego prawa rodziny: „Rodzice mają prawo do swobodnego wyboru szkół lub innych środków niezbędnych do kształcenia dzieci, zgodnie z własnymi

${ }^{36}$ B. Szacka, Wprowadzenie do socjologii, Warszawa 2008, s. 82.

${ }^{37}$ Zob. A. Dudek, Kultura, s. 259-262.

${ }^{38}$ Por. L. Dyczewski, Rodzina twórca i przekazicielem kultury, Lublin 2003, s. 41-44; tenże, Rodzina..., s. 106.

${ }^{39} \mathrm{KPR}$, art. 2.

${ }^{40}$ Por. KPR, art. 5; por. również: A. L. Trujillo, dz. cyt., s. 52n. 
przekonaniami"41. Zagwarantowanie swobody wyboru w kwestii edukacji potomstwa, o którym jest mowa w Karcie Praw Rodziny, leży w gestii państwa. Rządzący posiadają bowiem możliwość dotowania budżetów rodzinnych w sytuacji, kiedy nie jest możliwe zapewnienie równego dostępu do oferty wychowawczo-dydaktycznej, prezentowanej przez państwo w ramach systemu szkolnictwa ${ }^{42}$. Natomiast w zakresie treści nauczania szkoły powinny przekazywać wiedzę nie tylko teoretyczną, ale również praktyczną. Taki model edukacji służy komplementarnemu przygotowaniu członków rodziny do pełnego uczestnictwa w życiu społecznym. W gestii systemu edukacyjnego państwa leży również pogłębianie wychowania, mającego miejsce w formie pierwotnej na poziomie rodziny. Państwo powinno zadbać o transfer takich wartości, jak miłość, solidarność, poczucie sprawiedliwości itd. Ważnym zadaniem władzy jest także przekaz wiedzy w zakresu etosu narodowego, a więc kształcenie postaw patriotycznych wśród obywateli poprzez różnego rodzaju oddziaływania $^{43}$.

Trzeci kierunek oddziaływania państwa na rzecz rodziny w ramach polityki społecznej dotyczy kwestii materialnych. Działalność państwa w tym zakresie wyraża się w nadawaniu takich ram gospodarce, aby ta gwarantowała zachowanie postulatu płacy rodzinnej na rynku pracy. Jan Paweł II w encyklice Laborem exercens stwierdza, że płaca rodzinna „to znaczy jedno wynagrodzenie dane głowie rodziny za pracę, wystarczające na zaspokojenie potrzeb rodziny bez konieczności podejmowania pracy zarobkowej poza domem przez współmałżonka, czy to poprzez inne świadczenia społeczne, jak zasiłek rodzinny albo dodatek macierzyński dla kobiety, która oddaje się wyłącznie rodzinie; dodatek ten powinien odpowiadać realnym potrzebom, to znaczy uwzględniać liczbę osób pozostających na utrzymaniu w ciągu całego okresu, gdy

${ }^{41} \mathrm{KPR}$, art. 5.

${ }^{42}$ Por. tamże; Jan Paweł II, Szkoła i religia, „L'Osservatore Romano” 4/1981 (wyd. pol.), s. 14. Funkcja edukacyjna rodziny, jak dowodzi Jan Paweł II, dotyczy w pierwszej kolejności głoszenia Ewangelii poprzez własne czyny. Por. tenże, Rodzina w dziele ewangelizacji, „L'Osservatore Romano” 10/1981 (wyd. pol.), s. 21.

${ }^{43}$ Por. Jam Paweł II, W rodzinie czlowiek wzrasta, przez rodzine wchodzi do społeczeństwa, „L'Osservatore Romano" 2/1982 (wyd. pol.), s. 4n.; W. Półtawska, dz. cyt., s. 57; L. Dyczewski, Rodzina twórca i przekazicielem kultury..., s. 122-127; S. Olejnik, dz. cyt., s. 420n.; T. Szlendak, Socjologia rodziny. Ewolucja, historia, zróżnicowanie, Warszawa 2010, s. 245 . 
nie są w stanie podjać odpowiedzialności za własne życie" ${ }^{\prime 4}$. Założenie wspólnoty rodzinnej i trwanie w niej nie może być w żaden sposób źródłem dyskryminacji. Wychodząc naprzeciw zapotrzebowaniu rodzin, w ramach polityki społecznej należy wprowadzać różne działania o charakterze finansowym, takie jak pieniężne świadczenia społeczne, instrumenty umożliwiające godzenie obowiązków zawodowych i rodzinnych oraz ulgi podatkowe ${ }^{45}$.

Oddziaływanie państwa na rodzinę dotyczy nie tylko działań w ramach wskazanych powyżej kierunków; warto również zwrócić uwagę na możliwość interwencji państwa, rozumianej jako pomoc rodzinie, w wyjątkowych sytuacjach, gdy rodzina nie może realizować właściwych sobie funkcji. W Karcie Praw Rodziny jako nadzwyczajne określono następujące wypadki: „przedwczesna śmierć jednego lub obojga rodziców, opuszczenie rodziny przez jednego z małżonków, w razie wypadku, choroby czy inwalidztwa, w razie bezrobocia lub wtedy, gdy rodzina musi ponosić dodatkowe ciężary związane ze starością, niedorozwojem fizycznym czy umysłowym któregoś ze swych członków, czy też w związku z wychowywaniem dzieci"46. Żadne z działań państwa nie może jednak naruszać podmiotowości życia rodzinnego. Oznacza to, iż ingerencja państwa nie może być równoznaczna z uprzedmiotowianiem rodziny. Troska prospołeczna rządzących powinna bowiem sprzyjać wzrostowi odpowiedzialnej wolności rodziny, co jest równoznaczne z rozwojem osobowym ${ }^{47}$.

\section{ZAKOŃCZENIE}

Polityka prorodzinna oznacza priorytetowe zaangażowanie państwa na rzecz rodziny. Przyczyn aktywności państwa w tym zakresie jest bardzo wiele. Po pierwsze, misją władzy wynikającą z dobra wspólnego jest troska o zagwarantowanie integralnego rozwoju obywatelom i wspólnotom naturalnym. Po drugie, sposób funkcjonowania społeczności państwowej jest bezpośrednio zależny od charakteru życia rodzinnego. Po

${ }^{44}$ Jan Paweł II, Encyklika „Laborem exercens”, w: tenże, Encykliki, Kraków 1996, t. 1, 19 (cyt. dalej: LE); por. również: tenże, Kościót wobec największych problemów wspótczesnego świata, „L'Osservatore Romano” 1/1981 (wyd. pol.), s. 11.

${ }^{45}$ G. Firlit-Fesnak, dz. cyt., s. 196.

${ }^{46} \mathrm{KPR}$, art. 9.

${ }^{47}$ Por. L. Dyczewski, Rodzina, s. 101. 
trzecie, rodzina posiada zasadniczy udział w dobrobycie narodowym. Poczynania państwa sprzeczne $\mathrm{z}$ interesem rodziny są działaniem autodestrukcyjnym, prowadzącym do rozpadu tkanki społecznej.

Współczesne państwo stoi przed zadaniem stworzenia optymalnych warunków dla życia rodzinnego. Owa optymalizacja ma miejsce w obliczu licznych przemian gospodarczych, kulturalnych, politycznych itd. Ważne w tym układzie jest zachowanie modelu rodziny tradycyjnej, gwarantującego najwyższą ochronę godności osobowej oraz praw człowieka. Rodzina tradycyjna sprzyja również kształtowaniu wartości, takich jak solidarność, miłość i ofiarność, które nie tylko kształtują więź społeczną, ale nade wszystko określają relację jednostek i rodzin względem dobra wspólnego.

Państwo w ramach polityki prorodzinnej nie może pominąć znaczenia Kościoła, co dotyczy dwóch zasadniczych kwestii. Po pierwsze, nauczanie społeczne Kościoła odwołuje się do konkretnych zagadnień życia rodzinnego. Magisterium zwraca uwagę na zagrożenia życia rodzinnego oraz wskazuje na zasady, których realizacja może sprzyjać przezwyciężeniu sytuacji kryzysowych. Po drugie, Kościół umożliwia zachowania sakramentalnego wymiaru życia rodzinnego. Małżeństwo sakramentalne jest elementem konstytuującym życie rodziny. Udział rodziny w życiu sakramentalnym Kościoła umożliwia skuteczny postęp na drodze doskonałości chrześcijańskiej.

Podsumowując, trwanie chrześcijańskiego państwa jest zależne od istnienia rodziny w jej naturalnym wymiarze. Ów naturalny wymiar musi przy tym być zgodny z wolą Stwórcy.

\section{DER DIENST AN DER FAMILIE IM RAHMEN DER CHRISTLICHEN KONZEPTION DES STAATES}

\section{ZUSAMMENFASSUNG}

Die profamiliäre Politik bedeutet den vorrangigen Einsatz des Staates für die Familie. Das ist vielfach begründet. Zuerst: der Staat soll sich um die integrale Entwicklung der Einzelnen und der naturellen Gesellschaften kümmern. Zum zweiten: die Art und Weise der Tätigkeit des Staates ist vom Zustand der Familie abhängig. Zum dritten: die Familie besitzt das prinzipielle Teil am Wohlstand der Gesellschaft.

Die Publikation besteht aus zwei Teilen. Im ersten Teil wurde die Familie in ihren Hauptelementen dargestellf. Der Zweite Teil präsentiert die Beziehung der 
Familie zu Gesellschaft. Das dritte Teil stellt das Engagement des Staates für die Familie dar. Der Autor formuliert seine Thesen im Bezug auf die Soziallehre der Kirche. Man findet in der Publikation die wichtigsten Aussagen der Päpste (Johannes Paul II und Benedikt XVI), die den Bereich der Familie betreffen.

Man kann behaupten, dass die Existenz des Staates von der Familie in ihrer naturellen Dimension abhängig ist. 